\title{
Land Suitability Evaluation for Housing and Residential Based on GIS, Satellite Imagery and DTM
}

\author{
I M Purwaamijaya \\ \{ais_imp@upi.edu\} \\ Civil Engineering Department, Universitas Pendidikan Indonesia
}

\begin{abstract}
The aim of the research are making conceptual, functional model and implementing land suitability evaluation, creating database management system of land suitability evaluation, producing thematic map of land suitability evaluation for housing and residential based on GIS, satellite imagery and DTM. Research instruments are measurement and mapping tools, questionnaires, observations, computer hardware, and software. Primary data were taken by the physical, chemical and biological environment. Secondary data taken are maps of soil texture, soil drainage, soil type, erosion, slope, the effective depth of soil and flooding. Spatial analysis is used to superimpose layers, using GIS software. The thematic map which was producing land suitability evaluation for housing and residential based on GIS, satellite imagery, DTM from GIS software and satellite imagery from the internet could be more accurate and effective than conventional and analog methods.
\end{abstract}

Keywords: Land Suitability, Satellite Imagery, DTM, Housing and Residential

\section{Introduction}

Complex decisions within a short period of time when they must take into account sustainable development and economic competitiveness are often made by land-use planners. This respect is very useful for a set of land-use suitability maps. Complex criteria integrating several stakeholders' points of view should be incorporated by these maps. A small region realizes a land suitability map for housing to illustrate the feasibility of this approach. The criteria requested assessment to define the suitability of land for housing used Geographical Information System [1].

Rapid changes are being undergone and great attention worldwide is attracted by urban residential land. A better and more powerful understanding of urban residential land planning and improvement becomes essential from the quantitative evaluation of the suitability of urban residential land. Remote sensing data and GIS data are relied solely on to evaluate natural suitability, and few studies have focused on urban land suitability from a socioeconomic perspective. Remote sensing data and social sensing data are integrated to establish an evaluation framework for analyzing the suitability of urban residential land. Ecological comfortability, locational liveability, and overall suitability evaluate according to five attributes extracted from urban residential land via the factor analysis method [2].

Live of communes and settlement of particular areas to survive is mostly preferred by man. Communes and particular area physical appearances change continuously depending on the rapid growth in science and technology, the economic, cultural and social structures of the 
cities. The necessity of open green areas is usually ignored within this rapid and nonecological structural change and growth. Significant positive effects on man's psychological renewal, as well as social and cultural development, are had by open green areas. One of the important spaces in the urban environment that should be considered during the strategic environmental assessment (SEA) process of urban planning is had by open green areas. Determination of suitable lands for open green areas within the SEA process in the city center used Geographic Information System (GIS) and Remote Sensing (RS) techniques. Analyzing and overlaying hundreds of different data sources perform environmental and ecological planning studies. Environmental and ecological planning studies have been using the RS and GIS methodology compared with traditional assessment methodology [3].

A challenging issue for developing Asian countries due to limited flat land is rapid development geared towards hillsides. Various urban environmental problems, namely landslide susceptibility, soil, and coastal erosion and deforestation are created by rapid development geared towards hillsides. rapid development geared towards hillsides is very crucial that their location should be carefully chosen. A conceptual framework of understanding land evaluation using land suitability multi-criteria decision analysis (MCDA) approach considering accessibility is designed to develop a GIS-based land suitability analysis model and to formulate effective strategies for locating optimal sites to the hillside development against environmental threats and economic pull factor. The basic base for land suitability analysis in rational land-use planning using GIS use multi-criteria decision analysis (MCDA). Accessibility and topography, land cover, and economic incorporate in order to determine a suitable site. Acquisition of priority weights gathered by the expert opinions analyzed pair-wise comparison using the analytic hierarchy process (AHP) method in Expert Choice software [4].

Developing countries in the world are experiencing alarming urbanization. Historical changes in urban areas are analyzed using multi-temporal satellite imagery to identify areas that have increased or decreased. Base maps and Digital Elevation Model generation use CARTOSAT 1 and 2 high-resolution satellite data. The discovery of potential sites in hilly terrain for urban development using site suitability analysis techniques with a multi-criteria decision analysis (MCDA) approach is the research objective. AHP technique is used for the development of urban study areas in the analysis of site suitability. Discovery of new sites for urban expansion using criteria maps such as slope, aspect, altitude, road distance; land use/cover and lithology. Pairwise comparison matrices known as analytical hierarchy processes (AHP) are used to produce thematic layers (slope, aspect, height, etc.) of the standardized criteria. Comparisons with each other according to their interests determine the weights for each criterion/parameter. Assistance with weights and criteria for city expansion prepare a map of the suitability of the final location [5].

Different scales are used to observe various processes of forming land-use patterns. The measurements and quantitative description of land use patterns in land use modeling can be influenced by scale. Scale can significantly influence the behavior of model parameters that describe the process of land-use change. The results of a rigorous sensitivity analysis of the cellular urban land-use change model are presented and tested for their performance in response to various cell resolutions. The behavior of each type of urban growth rule across different cell sizes is specifically examined and the ability of the model to capture growth rates and patterns across scales is explored. The sensitivity to scale beyond the calibration problem is shown from the findings. Growth rates reliably in all cell sizes are able to be captured by the model. Very large cross-scale growth patterns are simulated based on differences in model capabilities. Significant differences in the sensitivity of growth rules across cell sizes were 
observed. The SLEUTH model can work better at certain cell sizes than others. The importance of scale consideration in research into modeling land-use change, especially in terms of determining the scale of investigations that are relevant and appropriate for the simulated process is emphasized by the research findings [6].

Fuzzy rules state semantic or linguistic knowledge about urban development. The potential for urban development for each pixel is determined based on the application of fuzzy inference. The potential for development to the level of environmental development needed is changed by the defuzzification process. Cellular automata as a preliminary estimate for its transition rules take the defuzzification process. Spatial calibration over cities and temporal calibration with multi-temporal satellite imagery updates such estimates. Three evaluation steps: Conformity and Type I and Type II errors are the basis for evaluating the modeling results. $80 \%$ of cities in the predicted growth of cities reach a fitness level of $100 \pm 20 \%$ with an average error of $30 \%$ [7].

Geometric information (area, perimeter, and centroid) of three types of forest were produced by a conceptual and functional model design and implementation. Multi-criteria evaluation of regional function using GIS was made by the standard operational procedure. Three types of forest are protected forest area, limited production forest area, and permanent production forest area. Multi-criteria evaluation is used to gain regional function by overlayed slope, soil and rainfall layers. Limited production forest area is bigger than the permanent production forest area and protected forest area. The conventional method is more difficult, slower and more expensive than the GIS method. Regional function table which is data structure combination of land slope, soil type, and rainfall automatically were produced by produced attribute table of regional function in district region [8].

An indispensable tool in land suitability evaluation, especially when the spatial problems are characterized by multiple alternatives is proven by the integration of Geographic Information System and Multi-Criteria Analysis. Soil erosion potential can be identified and assessed by a comprehensive methodology that integrates Remote Sensing and Geographic Information System, coupled with the use of an empirical model (Revised Universal Soil Loss Equation - RUSLE) to assess risk. The value of soil loss is estimated by the Remote Sensing and Geographic Information System based on the RUSLE model too. Rainfall erosivity (R), soil erodability (K), slope length and steepness (LS), cover management (C) and conservation practice $(\mathrm{P})$ factors are GIS data layers and were computed to determine their effects on average annual soil loss in the study area [9].

Survey, investigation, design, land acquisition, construction, operation and maintenance (SIDLaCOM) are through by construction process. The ISO 14001 elements of an environmental management system included environmental policy, planning, implementation, and operation, checking and corrective action, and management review. Environmental, physical, built, social and economic components summarize important components of quality of life for building construction projects. Screening, scoping, impact analysis, mitigation, reporting, review of EIA, decision making, and post monitoring are the eight steps of the EIA (Environmental Impact Assessment) process [10].

\section{Methods}

The documentary method was used for collecting soil texture, terrain slope, drainage, soil effective depth, soil wrinkle, and flood maps, the survey method was used for determining the 
position of soil investigation and observing housing development base on GPS receiver in the real world.

The documentary method go through stages, namely: (1) creating conceptual model for determining base map resource and resolution, (2) creating data instrument (3) collecting base map and statistical data, (3) classifying data, base on data type and resolution or scale, (4) digitizing base map and thematic maps, (5) creating attribute data structure, (5) inputting attribute data and connecting textual data with graphical data through a unique identifier, (6) creating digital thematic maps, (7) doing spatial analysis, (8) printing results map.

The survey method go through stages, namely: (1) preparing locations map, receiver GPS, and soil investigation instruments, (2) creating textual data instrument, (3) plotting survey location, (4) making survey license, (5) preparing finance and schedule, (6) go to survey locations, (7) taking notes and pictures in survey locations, (8) testing soil using sondir instrument, (9) making a resume.

\section{Result and Discussion}

\subsection{Digital Thematic Maps of Land Slope, Flood, Soil Texture, Soil Effective Depth, Soil Drainage, Soil Wrinkle.}

Digital thematic maps of land slope are shown in Figure 1, are contain 1 layer with 5 records, that are (1) rather steep, (2) steep, (3) flat, (4) sloping, and (5) very steep.

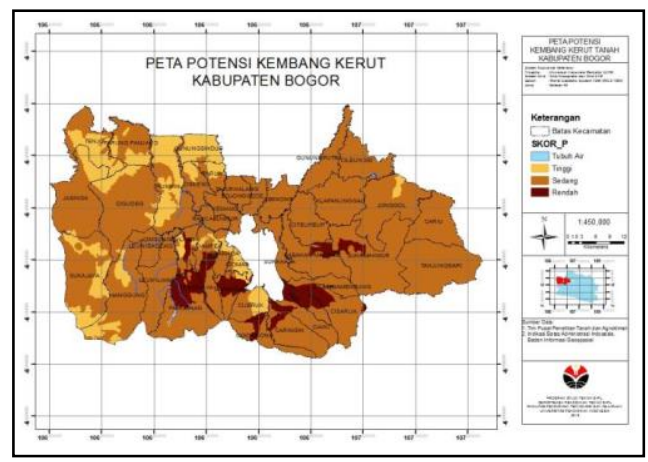

Fig. 1. Map of land slope of Bogor district.

Digital thematic maps of flood are shown in Figure 2, it contains 1 layer with 4 records, that are (1) not present, (2) sometimes, (3) often, and (4) water body. 


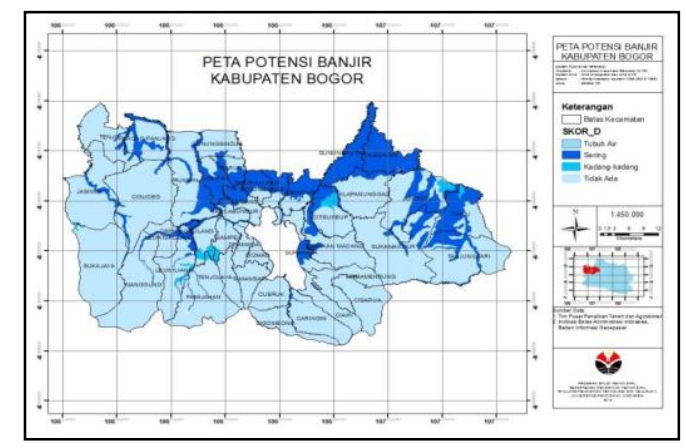

Fig. 2. Map of flood in Bogor district.

Digital thematic maps of soil texture shown in Figure 3, it contains 1 layer with 3 records, that are (1) smooth, (2) medium, and (3) rough.

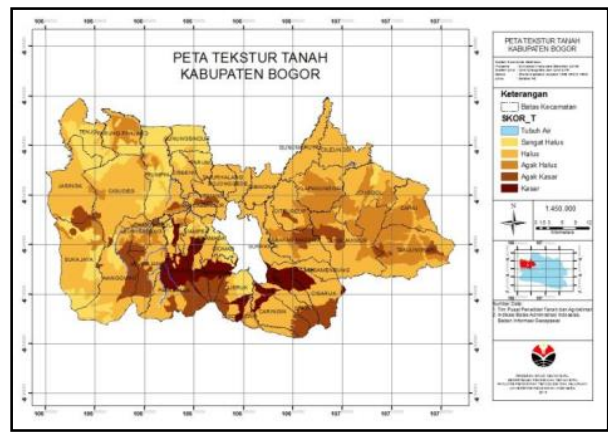

Fig. 3. Map of soil texture in Bogor district.

Digital thematic maps of soil effective depth are shown in Figure 4, it contains 1 layer with 4 records, that are (1) very shallow, (2) shallow, (3) medium, and (4) deep.

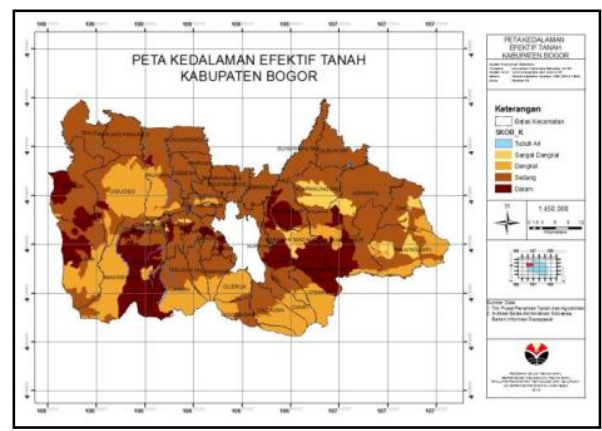

Fig. 4. Map of soil effective depth in Bogor district. 
Digital thematic map of soil drainage can be seen in Figure 5, it contains 1 layer with 5 records, that are (1) productive aquifer with wide distribution, (2) high productive aquifer with wide distribution, (3) high to moderate productive aquifer, (4) rare groundwater area, and (5) local small productive aquifer means.

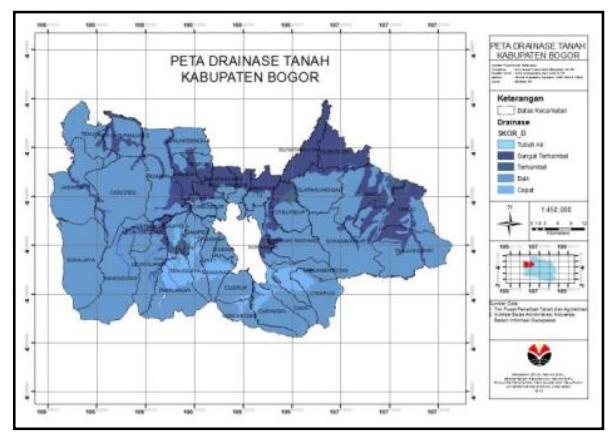

Fig. 5. Map of soil drainage in Bogor district.

Figure 6 are showing a digital thematic map of soil wrinkle contains 1 layer with 3 records, which are (1) high, (2) medium, (3) low.

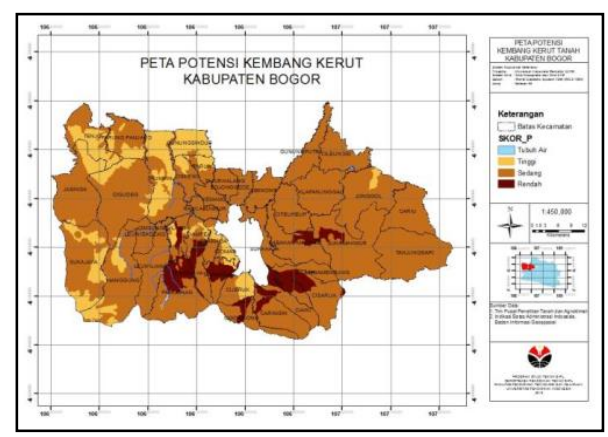

Fig. 6. Map of soil wrinkle in Bogor district.

\subsection{Digital Map of Land Suitability Evaluation for Housing}

Figure 7 are showing a digital thematic maps of land suitability evaluation for housing contain 1 layer with 3 records, which are (1) good, (2) medium, (3) poor. 


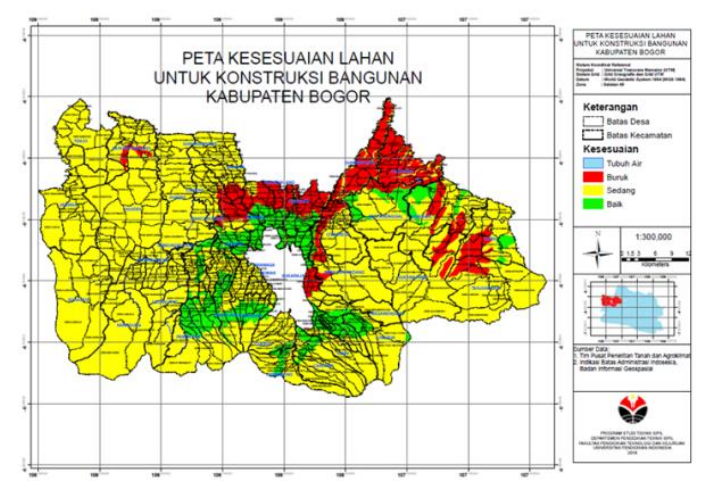

Fig. 7. Map of land suitability evaluation for housing in Bogor district.

\subsection{Conceptual, Functional Model and Implementation of Land Suitability Evaluation for Housing}

The conceptual model presents the linkage between the resulting feature and the users and resolution, the model can be seen in Table 1. There are 9 features consisting of a village, subdistrict, district, land slope, flood, soil texture, soil effective depth, soil drainage, and soil wrinkle. The resolution or scale field is consisting of the small, medium and big map. The users are consisting of land and building tax office, agrarian office, public works office, and environmental office. A conceptual model is used for determining the resolution/scale of the base map and institution resource.

Table 1. Conceptual model of land suitability evaluation for housing.

\begin{tabular}{|c|c|c|c|c|c|c|c|c|}
\hline \multirow[b]{2}{*}{ No } & \multirow[b]{2}{*}{$\begin{array}{c}\text { Spatial } \\
\text { information } \\
\text { (features) }\end{array}$} & \multicolumn{3}{|c|}{ Resolution / Scale } & \multicolumn{4}{|c|}{ Users } \\
\hline & & Small & Medium & Big & $\begin{array}{c}\text { Land and } \\
\text { Building } \\
\text { Tax } \\
\text { Office }\end{array}$ & $\begin{array}{c}\text { Agrarian } \\
\text { Office }\end{array}$ & $\begin{array}{l}\text { Public } \\
\text { Works } \\
\text { Office }\end{array}$ & $\begin{array}{c}\text { Environmental } \\
\text { Office }\end{array}$ \\
\hline 1. & Village & - & V & V & $\mathrm{V}$ & $\mathrm{V}$ & $\mathrm{V}$ & $\mathrm{V}$ \\
\hline 2. & Sub-district & - & $\mathrm{V}$ & $\mathrm{V}$ & V & V & V & $\mathrm{V}$ \\
\hline 3. & District & V & V & V & V & V & V & $\mathrm{V}$ \\
\hline 4. & Land slope & V & $\mathrm{V}$ & - & - & $\mathrm{V}$ & V & $\mathrm{V}$ \\
\hline 5. & Flood & V & $\mathrm{V}$ & V & - & $\mathrm{V}$ & V & $\mathrm{V}$ \\
\hline 6. & Soil texture & V & V & - & - & $\mathrm{V}$ & V & $\mathrm{V}$ \\
\hline 7. & $\begin{array}{c}\text { Soil effective } \\
\text { depth }\end{array}$ & V & $\mathrm{V}$ & - & - & V & - & $\mathrm{V}$ \\
\hline 8. & Soil drainage & V & V & - & - & V & - & $\mathrm{V}$ \\
\hline \multirow[t]{2}{*}{9.} & Soil wrinkle & V & V & - & - & $\mathrm{V}$ & V & V \\
\hline & Total & 7 & 10 & 4 & 3 & 10 & 6 & 10 \\
\hline
\end{tabular}

The functional model presents the relationship between the resulting feature and graphical information entity, the model can be seen in Table 2. There are 9 features consisting of a village, sub-district, district, land slope, flood, soil texture, soil effective depth, soil drainage, 
and soil wrinkle. The graphical information entity field is consisting of point, line, polygon, and annotation.

Table 2. Functional model of land suitability evaluation for housing.

\begin{tabular}{|c|c|c|c|c|c|}
\hline \multirow[b]{2}{*}{ No. } & \multicolumn{5}{|c|}{ Graphical Information Entity } \\
\hline & $\begin{array}{l}\text { Spatial information } \\
\text { (features) }\end{array}$ & Point & Line & Polygon & Annotation \\
\hline 1. & Village & $\mathrm{V}$ & - & $\mathrm{V}$ & $\mathrm{V}$ \\
\hline 2. & Sub-district & $\mathrm{V}$ & - & $\mathrm{V}$ & $\mathrm{V}$ \\
\hline 3. & District & $\mathrm{V}$ & - & $\mathrm{V}$ & $\mathrm{V}$ \\
\hline 4. & Land slope & $\mathrm{V}$ & - & $\mathrm{V}$ & $\mathrm{V}$ \\
\hline 5. & Flood & $\mathrm{V}$ & - & $\mathrm{V}$ & $\mathrm{V}$ \\
\hline 6. & Soil texture & $\mathrm{V}$ & - & $\mathrm{V}$ & $\mathrm{V}$ \\
\hline 7. & $\begin{array}{l}\text { Soil effective } \\
\text { depth }\end{array}$ & $\mathrm{V}$ & - & $\mathrm{V}$ & $\mathrm{V}$ \\
\hline 8. & Soil drainage & $\mathrm{V}$ & - & $\mathrm{V}$ & $\mathrm{V}$ \\
\hline 9. & Soil wrinkle & $\mathrm{V}$ & - & $\mathrm{V}$ & $\mathrm{V}$ \\
\hline & Total & 9 & 0 & 9 & 9 \\
\hline
\end{tabular}

Table 3 shows the implementation of land suitability evaluation for housing, it contains 4 phases, that are (1) base map digitization, (2) thematic map digitization and attributes input, (3) spatial analysis, (4) hardcopy. All phases were done using ArcGIS software.

Table 3. Implementation of Land Suitability Evaluation for Housing.

\begin{tabular}{|c|c|c|c|c|}
\hline No. & Activity & Input data & Output data & Software \\
\hline 1. & $\begin{array}{l}\text { Base map } \\
\text { digitization }\end{array}$ & $\begin{array}{l}\text { Base map } \\
\text { Village } \\
\text { Sub-district } \\
\text { District }\end{array}$ & Digital base map & ArcGIS \\
\hline 2. & $\begin{array}{l}\text { Thematic map } \\
\text { digitization and } \\
\text { attribute input }\end{array}$ & $\begin{array}{c}\text { Land slope } \\
\text { Flood } \\
\text { Soil texture } \\
\text { Soil effective depth } \\
\text { Soil drainage } \\
\text { Soil wrinkle }\end{array}$ & $\begin{array}{l}\text { Thematic maps } \\
\text { and textual tables }\end{array}$ & ArcGIS \\
\hline 3. & Spatial analysis & $\begin{array}{c}\text { Land slope } \\
\text { Flood } \\
\text { Soil texture } \\
\text { Soil effective depth } \\
\text { Soil drainage } \\
\text { Soil wrinkle }\end{array}$ & $\begin{array}{l}\text { Housing land } \\
\text { suitability zone } \\
\text { digital map }\end{array}$ & ArcGIS \\
\hline 4. & Hardcopy & $\begin{array}{l}\text { Housing land suitability zone digital } \\
\text { map }\end{array}$ & $\begin{array}{l}\text { Housing land } \\
\text { suitability zone } \\
\text { analog map }\end{array}$ & ArcGIS \\
\hline
\end{tabular}




\subsection{Characteristics of Soil Physic}

Characteristic of soil physics contains 11 fields with 9 records, that are (1) test number, (2) sample coordinates, (3) liquid limit, (4) plastic limit, (5) water content, (6) plasticity indexIp, (7) uniformity of coefficient- $\mathrm{Cu}$, (8) coefficient of gradation-Cc, (9) pass the filter \% no 10 , (10) pass the filter $\%$ no 40 , (11) pass the filter $\%$ no 200 . The analysis can be seen in Table 4.

Table 4. Analysis of Soil Physic Characteristic.

\begin{tabular}{|c|c|c|c|c|c|c|c|c|c|c|}
\hline \multirow[b]{2}{*}{$\begin{array}{c}\text { Test } \\
\text { Num } \\
\text { ber }\end{array}$} & \multirow[b]{2}{*}{ Coordinates } & \multirow{2}{*}{$\begin{array}{c}\% \\
\text { Liquid } \\
\text { Limit }\end{array}$} & \multirow{2}{*}{$\begin{array}{c}\% \\
\text { Plastic } \\
\text { Limit }\end{array}$} & \multirow{2}{*}{$\begin{array}{c}\% \\
\text { Water } \\
\text { Content }\end{array}$} & \multirow[b]{2}{*}{ Ip } & \multirow[b]{2}{*}{$\mathrm{Cu}$} & \multirow[b]{2}{*}{$\mathrm{Cc}$} & \multicolumn{3}{|c|}{ Pass the Filter } \\
\hline & & & & & & & & $\begin{array}{c}\text { No } \\
10\end{array}$ & $\begin{array}{r}\text { No } \\
40\end{array}$ & $\begin{array}{l}\text { No } \\
200\end{array}$ \\
\hline $\mathrm{R} 1$ & $\begin{array}{c}\text { Lat: } 6^{\circ} 29^{\prime} 25.40^{\prime \prime} \mathrm{S} \\
\text { Long: } 106^{\circ} 44^{\prime} 17.2 \\
0^{\prime \prime} \mathrm{E}\end{array}$ & 93 & 50.470 & 40.40 & 42.53 & 9.259 & 1.173 & 49 & 14 & 3 \\
\hline $\mathrm{R} 2$ & $\begin{array}{c}\text { Lat: } 6^{\circ} 29^{\prime} 56.29^{\prime \prime} \mathrm{S} \\
\text { Long: } 106^{\circ} 45^{\prime} 21.9 \\
4^{\prime \prime} \mathrm{E}\end{array}$ & 90 & 42.261 & 41.50 & 47.74 & 9.091 & 1.455 & 60 & 8 & 3 \\
\hline R3 & $\begin{array}{c}\text { Lat: } 6^{\circ} 29^{\prime} 17.00^{\prime \prime S} \\
\text { Long: } 106^{\circ} 43^{\prime} 5.60^{\prime \prime} \\
\mathrm{E} \\
\text { Lat. } 6^{\circ} 38^{\prime} 19.59^{\prime \prime} \mathrm{S}\end{array}$ & 90 & 57.298 & 31.10 & 32.70 & 12.27 & 1.684 & 49 & 6 & 2 \\
\hline Y1 & $\begin{array}{c}\text { Long: } 106^{\circ} 52^{\prime} 4.73^{\prime \prime} \\
\text { E }\end{array}$ & 75 & 46.883 & 30.73 & 28.12 & 9.000 & 1.235 & 51 & 11 & 1 \\
\hline $\mathrm{Y} 2$ & $\begin{array}{c}\text { Lat: } 6^{\circ} 40^{\prime} 46.10^{\prime \prime S} \\
\text { Long: } 106^{\circ} 51^{\prime} 4.90^{\prime \prime} \\
\mathrm{E}\end{array}$ & 57 & 33.935 & 42.35 & 23.07 & 10.58 & 1.511 & 65 & 19 & 3 \\
\hline Y3 & $\begin{array}{c}\text { Long: } 106^{\circ} 54^{\prime} 7.59^{\prime \prime} \\
\text { E }\end{array}$ & 85 & 46.412 & 30.95 & 38.09 & 8.077 & 2.637 & 44 & 11 & 2 \\
\hline G1 & $\begin{array}{c}\text { Lat: } 6^{\circ} 39^{\prime} 44.68 " \mathrm{~S} \\
\text { Long: } 106^{\circ} 50^{\prime} 56.5 \\
7 " \mathrm{E}\end{array}$ & 78 & 50.614 & 32.17 & 27.39 & 7.059 & 2.071 & 58 & 20 & 3 \\
\hline $\mathrm{G} 2$ & $\begin{array}{c}\text { Lat: } 6^{\circ} 39^{\prime} 51.03 " \mathrm{~S} \\
\text { Long: } 106^{\circ} 51^{\prime} 11.7 \\
9 " \mathrm{E}\end{array}$ & 59 & 44.049 & 28.18 & 14.95 & 8.333 & 0.784 & 68 & 26 & 4 \\
\hline G3 & $\begin{array}{c}\text { Lat: } 6^{\circ} 40^{\prime} 39.94 " \mathrm{~S} \\
\text { Long: } 106^{\circ} 51^{\prime} 57.9 \\
\text { 0"E }\end{array}$ & 63 & 45.063 & 24.50 & 17.94 & 7.500 & 0.833 & 65 & 18 & 1 \\
\hline
\end{tabular}

R1, R2, R3 located in "Bad" suitability.

Y1, Y2, Y3 located in "Medium" suitability.

G1, G2, G3 located in "Good" suitability. 


\section{Conclusion}

The final result of this land suitability analysis is the representation of the map, namely the Land Suitability Map for Housing in Bogor District with a scale of 1: 300,000. There are three zones of land suitability for Housing in Bogor Regency. Land with "Bad" suitability of 26,695.201 ha (11.061\%), land with suitability "Medium" of 190,112.656 ha (78.279\%), land with suitability "Good" amounted to 26,075.979 ha (10.660 \%). Some areas of Bogor District are in the "Medium" suitability zone. The location identified can be seen in the Land Suitability Map for Housing in Bogor District.

Acknowledgment. The author is grateful to the Directorate of Higher Education, Rector of Universitas Pendidikan Indonesia, Civil Engineering Department-Universitas Pendidikan Indonesia for providing data, recommendation, logistic and financial support.

\section{References}

[1] Joerin F, Theriault M, and Musy A.: Using GIS and outranking multicriteria analysis for land-use suitability assessment. International Journal of Geographical Information Science Tayor and Francis. vol. 15. ch. 2. pp. 153-174. (2001)

[2] Huang H, Li Q, and Zhang Y.: Urban Residential Land Suitability Analysis Combining Remote Sensing and Social Sensing Data: A Case Study in Beijing, China. Sustainability MDPI 11 2255. pp. $1-19(2019)$

[3] Cabuk SN, Uyguchil H, Cabuk A, and Inceoglu M.: Using GIS and RS Techniques for the Determination of Green Area Priorities within the Context of SEA. International Journal of Civil and Environmental Engineering. vol. 10. ch. 2 pp. $43-54$ (2010)

[4] Chandio I A, and Matori A N B.: Land Suitability Analysis Using Geographic Information System (GIS) for Hillside Development: A case study of Penang Island. International Conference on Environmental and Computer Science Research Gate 19. pp. 1-6 (2011)

[5] Singh S J, Chandel V, Kumar H, and Gupta H.: RS and GIS based urban land use change and site suitability analysis for future urban expansion Parwanoo planning area, Solan, Himachal Pradesh (India). International Journal of Development Research Research Gate. vol. 4. ch. 8. pp. 1491-1503 (2014)

[6] Jantz C A, and Goetz S J.: Analysis of scale dependencies in an urban land-use change model. International Journal of Geographical Information Science Taylor and Francis. vol. 19. ch. 2. pp. 217 $241(2005)$

[7] Al-Kheder S, Wang J, and Shan J.: Fuzzy inference guided cellular automata urban-growth modeling using muti-temporal satellite images. International Journal of Geographical Information Science Taylor and Francis. vol. 22. ch. 11-12. pp. 1271-1293 (2008)

[8] Masri R M, and Purwaamijaya I M.: Multi Criteria Evaluation for Regional Function Based on Geographic Information System. Proceeding - 2017 3rd International Conference on Science in Information Technology: Theory and Application of IT for Education, Industry and Society in Big Data Era, ICSITech 2017 IEEE 17472603. pp. 1-5 (2018)

[9] Purwaamijaya I M. Multi citeria evaluation for universal soil loss equation based on geographic information system. Journal of Physics: Conference Series IOP 10132018 012153. pp. 1-7 (2018)

[10] Masri, RM.: Environmental management and monitoring for education building development. Journal of Physycs: Conference Series IOP 10132018 012105. pp. 1-9 (2018) 